\title{
Effects of ensiling time on corn silage neutral detergent fiber degradability and relationship between laboratory fiber analyses and in vivo digestibility
}

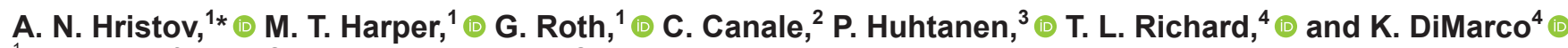 \\ ${ }^{1}$ Department of Animal Science, The Pennsylvania State University, University Park 16802 \\ ${ }^{2}$ Cargill Animal Nutrition, Shippensburg, PA 17257 \\ ${ }^{3}$ Department of Agricultural Science for Northern Sweden, Swedish University of Agricultural Sciences, SE-901 87 Umeå, Sweden \\ ${ }^{4}$ Department of Agricultural and Biological Engineering, The Pennsylvania State University, University Park 16802
}

\begin{abstract}
Accurate analysis of degradability of silage neutral detergent fiber (NDF) is important for diet formulation and to predict lactational performance of dairy cows. In this study, 5 corn silage hybrids ensiled for 0 (unfermented), 30, 60, 120, and $150 \mathrm{~d}$ were used to determine the effects of ensiling time on silage neutral detergent fiber degradability (NDFD) and to assess the relationships between near-infrared reflectance spectroscopy (NIR) NDF-related analyses and in situ NDFD variables. In addition, the relationships between dietary concentration of indigestible NDF, 288-h incubation (iNDF288), or undegraded NDF, 240-h incubation (uNDF240), and in vivo total-tract apparent organic matter and NDF digestibility were studied in total mixed ration samples from 16 experiments with lactating dairy cows. Ensiling time had no effect on silage NDF concentration; however, the ratio of acid detergent fiber $\div \mathrm{NDF}$ increased, and estimated hemicellulose concentration decreased quadratically with ensiling time. Also, concentration of NDF-bound protein decreased, and that of lignin increased linearly with ensiling time. These changes in silage fiber composition resulted in a linear decrease in in situ effective degradability of silage NDF with increasing ensiling time. The indigestible fraction of NDF and concentration of structural carbohydrates were not affected by ensiling time. Correlations of in situ NDFD variables with laboratory NIR NDFD analyses were weak to moderate. The relationship of corn silage uNDF240 with lignin concentration or 30-h NDFD (all NIR analyses) was remarkably good $\left(\mathrm{R}^{2}=\right.$ 0.73 and 0.88 , respectively). The relationship between in situ iNDF288 concentration (but not uNDF240) and in vivo total-tract apparent digestibility of dietary organic matter and NDF was good $\left(\mathrm{R}^{2}=0.72\right.$ and 0.80 ,
\end{abstract}

Received May 6, 2019.

Accepted November 3, 2019.

*Corresponding author: anh13@psu.edu respectively). In conclusion, in situ degradability of silage NDF linearly decreased from 0 to $150 \mathrm{~d}$ ensiling time, primarily caused by a decrease in concentrations of hemicellulose and NDF-bound protein. In situ NDF degradability measurements and common laboratory NIR NDF-related analyses were generally poorly correlated. We found a good relationship between in vivo NDF digestibility and dietary concentration of iNDF288 determined in situ, but the relationship with uNDF240 was poor.

Key words: neutral detergent fiber, method of analysis, digestibility, corn silage

\section{INTRODUCTION}

Forages are the main feed ingredients in dairy rations in the Northeast and throughout the United States (Mowrey and Spain, 1999; Hristov et al., 2006; Weeks et al., 2015), and forage $\mathrm{NE}_{\mathrm{L}}$ commonly represents $40 \%$ or more of the total $\mathrm{NE}_{\mathrm{L}}$ intake in dairy cows. As a result, variability in forage quality and specifically forage fiber digestibility dominate the variability in overall digestibility of dairy rations, and it has been shown that forage NDF digestibility (NDFD) may help in predicting DMI and lactational performance of dairy cows (Oba and Allen, 1999). In support of this, a metaanalysis by Nousiainen et al. (2009) of data from 92 studies concluded that changes in dietary NDF concentration and digestibility were the most important factors determining OM digestibility in dairy cows.

Because of the importance of forage fiber digestibility for animal performance, developing standardized in vitro (IV) or in situ (IS) procedures for estimating fiber digestibility has been a primary goal for animal scientists (Jung, 1997). Various methods, including IV, IS, and more recently near-infrared reflectance spectroscopy (NIR), for rapid laboratory evaluation of forage NDF digestibility, have been developed (Van Soest et al., 1966; Mehrez and Ørskov, 1977; Combs, 2013; Raffrenato et al., 2018). These methods, however, can yield widely different NDFD estimates (Bender et al., 
2016), affecting practical decisions related to the nutritive value of forages, when incorporated into ration formulation programs and used to predict forage and diet digestibility and production responses. An analysis of data from The Pennsylvania State University's Commercial Silage Hybrid Corn Test Program (PSUCSTP; https://extension.psu.edu/2018-results-pa-commercial -grain-and-silage-hybrid-corn-tests-report\#section-13, accessed Mar. 15, 2019), which is designed to help dairy producers select corn silage hybrids for their forage program, showed (1) good agreement [correlation and concordance correlation (CCC; Lin, 1989) coefficients of 0.96 for NDF concentration between wet chemistry and NIR methods (both conducted at Cumberland Valley Analytical Services, Waynesboro, PA; CVAS), but $(2)$ poor correlation $(\mathrm{r}=0.49)$ and $\mathrm{CCC}(\mathrm{CCC}=$ 0.24 ) between methods for 30-h IV NDFD (NDFD30; unpublished data by A. N. Hristov, The Pennsylvania State University). This discrepancy suggests the need for a re-evaluation of the laboratory methods used for analysis of forage fiber digestibility.

Digestibility of NDF of corn silage, which is the main forage in North American dairy rations, can have a profound effect on cow productivity. Dietary substitution (on DM basis) of a silage corn hybrid with high NDF digestibility for a hybrid with low NDF digestibility was associated with increased DMI (faster passage rate) and milk production (Ivan et al., 2005); however, no production effects were observed for substitution on an NDF basis. Ensiling time can also influence silage digestibility, which can have implications in practical ration formulation. It is known that corn silage starch digestibility increases with ensiling time (Der Bedrosian et al., 2012; Ferraretto et al., 2015; Harper et al., 2016), but the effect of ensiling time on NDF digestibility appears to be inconsistent (Sanderson, 1993; Cherney et al., 2007; Der Bedrosian et al., 2012) and may depend on the method of analysis.

Therefore, this study was conducted with the main objective of evaluating the effects of ensiling time on corn silage NDFD analyzed by IS and common laboratory NIR methods. Secondary objectives were to analyze the relationships between (1) corn silage NDFrelated analyses from 2 commercial laboratories and IS potentially degradable NDFD (pdNDFD) analysis conducted at The Pennsylvania State University, and (2) laboratory indigestible NDF (iNDF, determined by 288-h IS incubation; i.e., iNDF288) or undegraded NDF (uNDF, determined by 240-h IV incubation; i.e., uNDF 240) analyses and in vivo apparent total-tract $\mathrm{OM}$ and NDF digestibility in dairy cows. We expected that achieving these objectives would provide PSUCSTP with useful information for evaluating corn silage hybrids for the dairy industry in the Northeast. We hy- pothesized that (1) corn silage pdNDFD changes with ensiling time, (2) there will be substantial differences between IS pdNDFD and NIR NDF-related analyses of corn silage samples, and (3) iNDF288 and uNDF240 are related to in vivo NDF digestibility.

\section{MATERIALS AND METHODS}

All study procedures involving animals were reviewed and approved by The Pennsylvania State University's Institutional Animal Care and Use Committee.

\section{Corn Silage Hybrids and Analyses}

A selection of silage corn hybrids included in the 2014 PSUCSTP (https://extension.psu.edu/pa-commercial -grain-and-silage-hybrid-corn-test-results-archive; accessed Mar. 15, 2019) were used in the study. The corn silage hybrids were as follows: Hubner H5333RC3P (HUB1), H6191RCSS, and H5222RC3P (Hubner Seed, Monticello, IN), Masters Choice MC 5250 (MC; Masters Choice, Anna, IL), and Healthy Herd Genetics 42HFC15 (HHG; Healthy Herd Genetics and Nutrition, Greenport, NY). Three of these hybrids were rated (by the seed company) as potentially high in starch degradability, whereas the other 2, Hubner 5333 and Hubner 6191, were rated low to medium starch degradability, respectively. The corn plants were grown in Centre County, Pennsylvania, at The Pennsylvania State University's Russell Larson Research Farm. Each hybrid was grown on 3 separate plots. After harvest, plants were ensiled (in triplicate) in sealed $2.5-\mathrm{kg}$ capacity plastic bags. Silages were stored at room temperature (around $23^{\circ} \mathrm{C}$ ) and moved to a $-20^{\circ} \mathrm{C}$ freezer on d 0 (unfermented), 30,60, 120, and 150 post-ensiling and stored frozen for at least $30 \mathrm{~d}$ before analysis. Subsamples of the silages were dried at $55^{\circ} \mathrm{C}$ for 72 $\mathrm{h}$, ground for further analysis through a $4-\mathrm{mm}$ (for IS degradability) or 1-mm (for chemical analyses) sieve in a Wiley mill (Thomas Scientific, Swedesboro, NJ).

\section{In Situ}

Corn silage samples ground through a 4-mm sieve were assessed for ruminal degradability (disappearance) of potentially degradable NDF (pdNDF) using the IS method. Three ruminally cannulated (10-cm internal diameter cannulas; Bar Diamond Inc., Parma, ID) lactating Holstein cows (average \pm SD: $\mathrm{DMI}=26.8$ $\pm 1.0 \mathrm{~kg} / \mathrm{d}$; milk yield $=39.8 \pm 2.96 \mathrm{~kg} / \mathrm{d}$; and DIM $=170 \pm 10.8 \mathrm{~d}$ ) were used for IS incubations. Cows were fed a standard $60 \%$ forage and $40 \%$ concentrate feed ration based on corn silage, alfalfa haylage, grass hay, ground corn grain, whole roasted soybeans, canola 
meal, and a mineral and vitamin premix. Approximately $7 \mathrm{~g}$ of silage $\mathrm{DM}$ were weighed into $10 \times 20-\mathrm{cm}$ nylon bags with $50 \pm 10-\mu \mathrm{m}$ porosity (ANKOM Technology Corp., Macedon, NY) and closed with a ziptie after folding. Duplicated bags were sequentially incubated in each cow for 0 (not incubated in the rumen), 4, 8, $12,24,48$, and $72 \mathrm{~h}$, and removed simultaneously. The 0-h samples were processed in the same way as the incubated samples, excluding the rumen incubation step. Upon removal from the rumen, bags were rinsed 3 times with cold water in a washing machine set to agitate for 6 min each rinse. Further details on the IS procedure can be found in Harper et al. (2017b). Silage samples and IS bag residues were analyzed for NDF with an ANKOM 200 fiber analyzer (ANKOM Technology Corp.), based on the procedures of Van Soest et al. (1991) with $\alpha$-amylase and sodium sulfite (both from ANKOM Technology Corp.). Ruminal disappearance was calculated based on initial dry weight of the incubated sample, residue dry weight, and NDF concentration of initial sample and bag residue. Potentially degradable NDF was estimated as follows:

$$
\begin{gathered}
\operatorname{pdNDF}(\% \text { of DM })=\text { total NDF }(\% \text { of DM }) \\
- \text { iNDF288 }(\% \text { of DM }) .
\end{gathered}
$$

Ruminal IS degradability of pdNDF was estimated based on pdNDF concentration in the silage samples, total NDF IS degradability data, and the assumption that iNDF288 does not disappear and is not degraded during IS incubation and total NDF disappearance equals pdNDF disappearance. Degradation curves were fit to the equation $p=a+b\left(1-\mathrm{e}^{-c t}\right)$, where $p$ (\% of pdNDF) is the degraded fraction of silage pdNDF at time $t, a(\%)$ is the soluble pdNDF or the fraction of pdNDF lost through the bag, $b(\%)$ is the potentially degradable fraction of pdNDF, and $c(\% / \mathrm{h})$ is the rate (ISpdRate) of degradation of fraction $b$ (Ørskov and McDonald, 1979); it was assumed that $a+b \leq 100 \%$. The effective degradability of pdNDF (ISpdED, \%) was determined using the following equation (Ørskov and McDonald, 1979):

$$
\operatorname{ISpdED}=a+b[c /(c+k)],
$$

where $a, b$, and $c$ are as specified above and $k$ is the rate of passage, assumed to be $2 \% / \mathrm{h}$ (based on average rate of passage of iNDF from the meta-analysis of Krizsan et al., 2010).

Corn silage samples were also analyzed for iNDF288 via 12-d (288-h) ruminal IS incubation, as described in Huhtanen et al. (1994), except that filter bags of $25-\mu \mathrm{m}$ pore size (ANKOM Technology Corp.) were used for the ruminal incubation (Lee et al., 2012).

\section{Laboratory Analyses}

Corn silage samples were submitted to 2 commercial feed analysis laboratories, Rock River Laboratories Inc. (Watertown, WI; LabA) and CVAS (LabB). With the exceptions specified below, all analyses presented here were performed using NIR procedures; specifics can be found at https://www.rockriverlab.com/pages/ Animal-Nutrition-Analysis.php (LabA; accessed Apr. $25,2019)$ and at https://www.foragelab.com/Lab -Services/Forage-and-Feed/NIR (LabB; accessed Apr. 25, 2019). Laboratory A analyzed the silage samples for amylase-treated NDF (aNDF), lignin, standardized 30-h NDF digestibility (sNDFD30), potentially degradable NDF at $240 \mathrm{~h}$ (pdNDFD240; Goeser et al., 2009), and total-tract NDF digestibility (TTNDFD; Combs, 2013; Lopes et al., 2015). The calibration method for NIR aNDF for LabA was that of Van Soest et al. (1991; with sulfite). Laboratory B analyzed the samples for aNDF and ADF (on separate samples, by wet chemistry methods), aNDF on an ash-free basis (aNDFom), neutral detergent insoluble CP (NDICP), lignin, NDFD30, uNDF240, rate of NDF digestion (kdNDF; Van Amburgh et al., 2003), and other silage quality-related analyses presented in Table 1, footnote 6. Calibration methods for NIR aNDFom and NDFD30 for LabB were Van Soest et al. (1991; with sulfite) and Goering and Van Soest (1970; restricted to 30-h incubation), respectively.

Similar to IS pdNDF, degradation rate for NIR pdNDF (kdNDFLabA) was estimated from the standardized NDFD (sNDFD, 24-, 30-, and 48-h) analyses by LabA and pdNDFD240. Further, undegraded NDF at $240 \mathrm{~h}$ by NIR for LabA (uNDFLabA) was calculated as 100 - pdNDFD240. For LabB, uNDF was also calculated as lignin $\times 2.4(\mathrm{uNDFLigB})$.

Silage samples from d 0, 30, and 150 were dried at $55^{\circ} \mathrm{C}$ and ground through a $1-\mathrm{mm}$ sieve, as described above, pretreated with $\alpha$-amylase to remove starch (ANKOM fiber analyzer; see above), and then analyzed for total lignin as well as insoluble carbohydrates (glucan, xylan, galactan, and arabanan) using wet chemistry methods developed by the National Renewable Energy Laboratory (NREL; Sluiter et al., 2006, 2008). Acidsoluble lignin was determined from the acid-hydrolyzed samples by ultraviolet-visible spectrometry at $320 \mathrm{~nm}$, then added to the acid-insoluble lignin as determined by gravimetric analysis of the residues from the sulfuric acid extraction, corrected for ash and protein content, to calculate total lignin (Sluiter et al., 2008). The 
Table 1. Descriptive statistics of in situ NDF degradability variables and selected near-infrared reflectance spectroscopy (NIR) analyses of corn silage hybrids ensiled for 0 to $150 \mathrm{~d}^{1}$

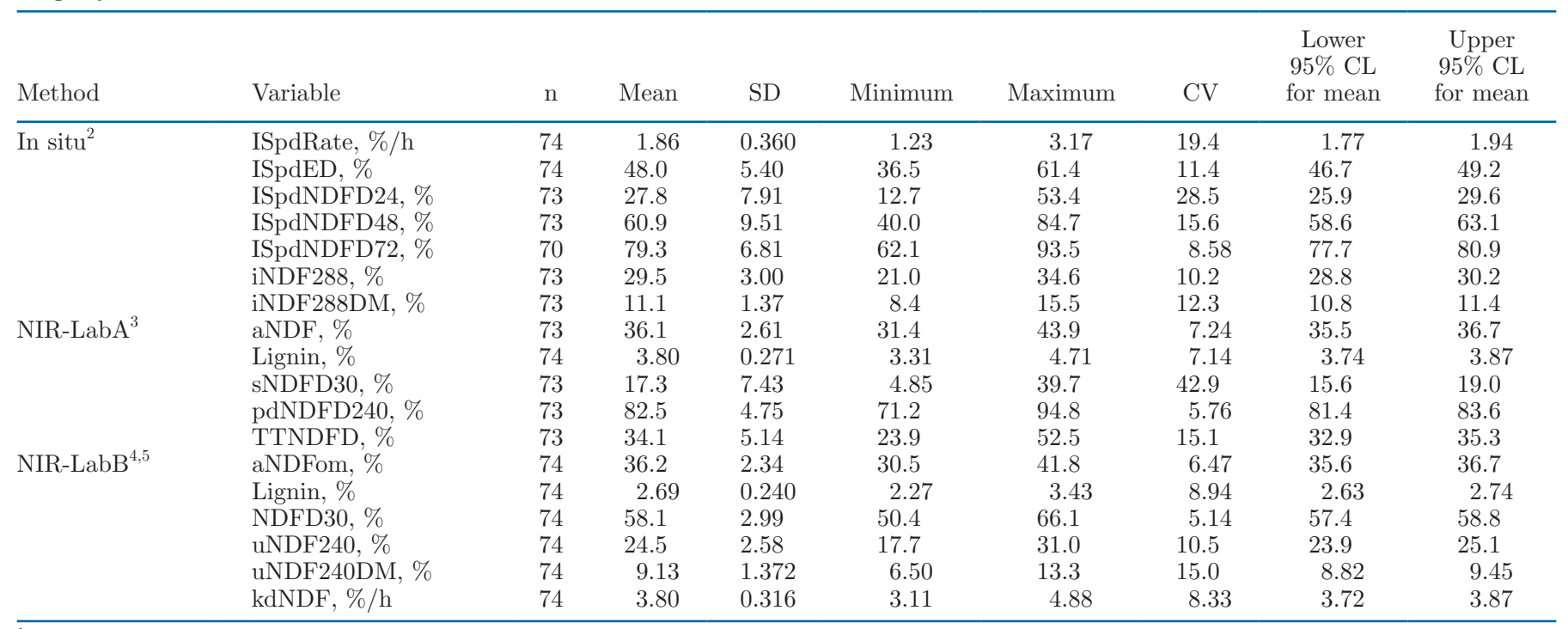

${ }^{1}$ The following hybrids were included in the study: Hubner H5333RC3P, H6191RCSS, and H5222RC3P (Hubner Seed, Monticello, IN); Masters Choice MC 5250 (Masters Choice, Anna, IL); and Healthy Herd Genetics 42HFC15 (Healthy Herd Genetics and Nutrition, Greenport, NY). n $=$ number of observations; $\mathrm{CL}=$ confidence limit.

${ }^{2}$ The in situ experiment was conducted at The Pennsylvania State University (University Park, PA; see Materials and Methods for details); ISpdRate $=$ rate of in situ degradation of potentially degradable NDF, $\% / \mathrm{h}$; ISpdED $=$ in situ effective ruminal degradability of potentially degradable NDF, estimated at $2 \% / \mathrm{h}$ passage rate, \% of NDF; ISpdNDFD24, ISpdNDFD48, and ISpdNDFD72= in situ 24-, 48-, and 72-h degradability of potentially degradable NDF, respectively, $\%$ of NDF; iNDF288 $=288$-h in situ indigestible NDF, $\%$ of NDF; iNDF288DM $=$ 288-h in situ indigestible NDF, \% of DM.

${ }^{3}$ LabA (Rock River Laboratories Inc., Watertown, WI); analyses were from LabA's Comprehensive Nutrition package: aNDF and aNDFom $=$ amylase-treated NDF and amylase-treated NDF on an ash-free basis, respectively, $\%$ of DM; lignin = lignin, \% of DM; sNDFD30 = standardized NDF degradability at 30 h, \% of NDF (Goeser et al., 2009); pdNDFD240 = potentially degradable NDF at 240 h, $\%$ of NDF (Lopes et al., 2015); TTNDFD = total-tract NDF digestibility, \% of NDF (Combs, 2013; Lopes et al., 2015).

${ }^{4}$ LabB (Cumberland Valley Analytical Services, Waynesboro, PA); analyses were from LabB's NIR Plus Option package: aNDFom = amylasetreated NDF on an ash-free basis, \% of DM; lignin = lignin, \% of DM; NDFD30 = NDF degradability at $30 \mathrm{~h}, \%$ of NDF; uNDF240 = undegraded NDF at $240 \mathrm{~h}, \%$ of NDF; uNDF240DM = undegraded NDF at $240 \mathrm{~h}, \%$ of DM; kdNDF = rate of NDF degradation, as determined by Cumberland Valley Analytical Services, based on Van Amburgh et al. (2003), \%/h.

${ }^{5}$ Additional analyses of the silages (mean \pm SD; NIR analyses by Cumberland Valley Analytical Services) not included in this table: $\mathrm{pH}=3.86$ $\pm 0.08 ; \mathrm{CP}, \%=7.0 \pm 0.47$; starch, $\%=34.3 \pm 2.76 ; 7$-h starch digestibility, $\%$ of starch $=74.2 \pm 4.82 ;$ ADF, $\%=21.6 \pm 1.92 ;$ ADF-insoluble $\mathrm{CP}, \%$ of $\mathrm{CP}=10.0 \pm 1.08 ; \mathrm{NDF}$-insoluble $\mathrm{CP}, \%$ of $\mathrm{NDF}=13.0 \pm 1.69 ;$ ADF-insoluble $\mathrm{CP}, \%$ of $\mathrm{ADF}=9.9 \pm 1.08$; ether extract, $\%=3.3$ \pm 0.23 ; ash, $\%=2.9 \pm 0.48 ; \mathrm{Ca}, \%=0.15 \pm 0.02$; lactic acid, $\%$ of $\mathrm{DM}=4.10 \pm 1.27$; acetic acid, $\%$ of $\mathrm{DM}=0.93 \pm 0.048 ;$ propionic acid, $\%$ of DM $=0.38 \pm 0.010$; butyric acid, not detected; and total VFA (lactic acid and acetic, propionic, butyric, and isobutyric acids), \% of DM $=5.39 \pm 1.55$

method for insoluble carbohydrates was modified as described by Essien and Richard (2018). In brief, to $5 \mathrm{~g}$ of sample DM were added $10 \mathrm{~mL}$ of distilled water and sufficient sulfuric acid to reach $4 \%$ sulfuric acid concentration; then the mixture was autoclaved at $121^{\circ} \mathrm{C}$ for 1 h. These acid-hydrolyzed samples were filtered through $0.22-\mu \mathrm{m}$ polytetrafluoroethylene filters and diluted $400-$ fold before sugar monomer analysis by ion exclusion chromatography (Thermo Fisher Scientific Inc., Dionex ICS 3000, Sunnyvale, CA). Sugar separation was performed using a CarboPac PA20 guard (Dionex; $3 \times 30$ $\mathrm{mm})$ and analytical $(3 \times 150 \mathrm{~mm})$ columns at $30^{\circ} \mathrm{C}$ with $2 \mathrm{mM} \mathrm{NaOH}$ at a flow rate of $0.5 \mathrm{~mL} / \mathrm{min}$, with identification and quantification of the monosaccharides by pulsed amperometric (electrochemical) detection at gold working electrodes, using a quadruple waveform. Glucan, xylan, galactan, and arabanan were calculated from glucose, xylose, galactose, and arabanose concentrations, using conversion factors of $0.88,0.90,0.88$, and 0.90, respectively (Sluiter et al., 2008).

\section{In Vivo Total-Tract Apparent Digestibility}

Total mixed ration samples from experiments conducted at The Pennsylvania State University (PSU, University Park, PA; 46 samples from 12 experiments) and at the Swedish University of Agricultural Sciences (SLU, Umeå, Sweden; 17 samples from 4 experiments) were analyzed for iNDF288 (Huhtanen et al., 1994 for the SLU samples, or as described above for the PSU 


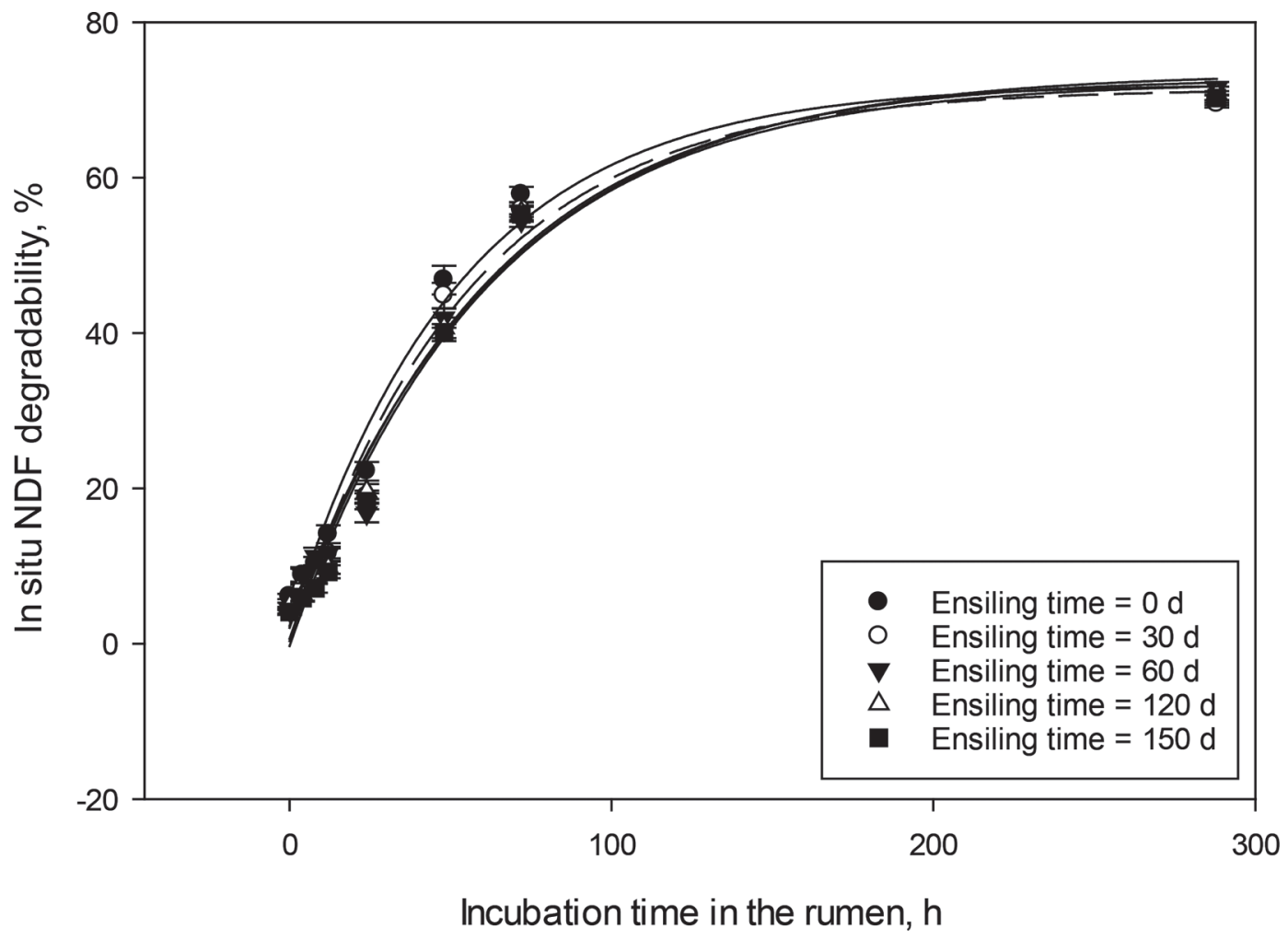

Figure 1. Corn silage in situ total NDF degradability (\% of NDF). Data are mean \pm SE (error bars), averaged across 5 hybrids. Data were fitted to a single, 3-parameter exponential rise to a maximum model (SigmaPlot 13.0; Systat Software, Chicago, IL): $\mathrm{p}=\mathrm{a}+\mathrm{b} \times[1-\exp (-\mathrm{c}$ $\times \mathrm{t}$ )], where $\mathrm{p}$ is the fraction of total NDF degraded or disappeared from the in situ bag (\%); a is the intercept (soluble or rapidly degraded total $\mathrm{NDF}$, \%; $\mathrm{b}$ is the potentially degradable total NDF, \%; $\mathrm{c}$ is the rate of degradation of fraction b, \%/h; and $\mathrm{t}$ is incubation time, h. Degradability at $288 \mathrm{~h}$ is from the iNDF288 analysis (see Materials and Methods). Regression, $P<0.001 ; \mathrm{R}^{2}$ for $0-,, 30-, 60-, 120-$, and $150-\mathrm{d}$ ensiling time $=$ 0.98 to 1.00 . Solid line $=0$-d silage; long-dash line $=30$-d silage; remaining regression lines are for 60 - to 150 -d silages and are indistinguishable on this graph.

samples) and uNDF240 by CVAS as described above. The PSU TMR samples were from the following experiments: Giallongo et al. (2015, 2016, 2017), Harper et al. (2017a, 2017b, 2018, 2019), Lopes et al. (2017), Oh et al. (2017, 2019), Melgar et al. (2018), and Räisänen et al. (2018). The SLU TMR samples were from the following experiments: Cabezas-Garcia et al., 2017; Krizsan et al., 2017; Pang et al., 2018; and D. Pang, S. J. Julie Krizsan, T. Yan, and P. Huhtanen, unpublished. The TMR were analyzed for apparent total-tract digestibility (ATTD) of OM and NDF in the original experiments. In all experiments, except that of Räisänen et al. (2018), ATTD was determined using iNDF288 as intrinsic digestibility marker; ATTD in Räisänen et al. (2018) was analyzed using total fecal collection.

\section{Statistical Analysis}

All data were analyzed using SAS version 9.4 (SAS Institute Inc., Cary, NC). The MEANS procedure was used for descriptive statistics of the laboratory and IS analyses of the silage samples and in vivo ATTD data.
The CORR procedure was used to derive Pearson correlation coefficients for the relationship of IS NDFD variables with laboratory NIR analyses. Effects of hybrid and ensiling time on corn silage composition, cell-wall carbohydrates, and IS and NIR NDF degradability variables were analyzed using the GLIMMIX procedure. The model contained hybrid, ensiling time, and hybrid $\times$ ensiling time interaction and orthogonal polynomial contrasts were used to evaluate linear and quadratic effects of ensiling time. Data are presented as least squares means. Plotting and curve-fitting of data for Figures 1, 2, 3, and 4 was performed using SigmaPlot 13.0 (Systat Software, Chicago, IL). Statistical differences were considered significant at $P \leq 0.05$ and trends at $0.05<P \leq 0.10$.

\section{RESULTS AND DISCUSSION}

\section{Chemical Analyses and In Situ Degradability}

Descriptive statistics of IS and NIR fiber-related analyses of the corn silage samples are shown in Table 

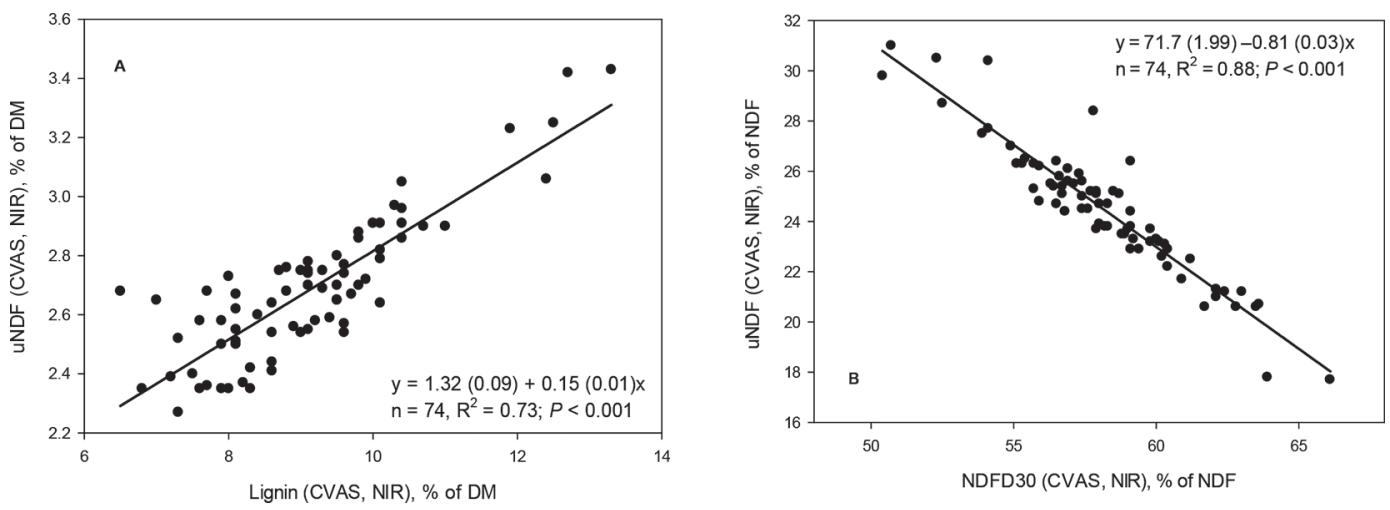

Figure 2. Relationship of lignin (\% of DM, panel A) or 30-h NDF degradability (\% of NDF, NDFD30, panel B) with undigested NDF (uNDF; \% of DM, panel A; or \% of NDF, panel B) in corn silage hybrids ensiled for 0 to $150 \mathrm{~d}$. CVAS = Cumberland Valley Analytical Services (Waynesboro, PA); NIR = near-infrared reflectance spectroscopy.

1. All silages were well preserved (based on silage $\mathrm{pH}$ and concentration of lactic acid) and of high nutritional quality (based on starch content, 7-h starch digestibility, and NDFD30; Table 1, footnote 6). In situ degradability parameters and NIR analyses were within expected ranges for corn silage. The largest variation was observed for NIR sNDFD30 (LabA; CV $=42.9 \%)$ and IS 24-h extent of pdNDFD (ISpdNDFD24). Compared with Bender et al. (2016), who analyzed 13 corn silage samples from a commercial forage analyses laboratory, silage hybrids used in the current study had higher average starch concentration (27.7 vs. $34.3 \%$, respectively), similar NDF, uNDF240, and TTNDFD, and comparable lignin concentration (2.8 vs. 3.80 or $2.69 \%$, for LabA and LabB, respectively). Digestibility of NDF at $30 \mathrm{~h}$ was also similar for silages from the current study and the DairyOne database (https://dairyone.com; accessed Mar. 20, 2019) for Pennsylvania 2014-15 corn silages. The average ISpdRate, however, were lower in the current study $(1.86 \% / \mathrm{h})$ than in that of Bender et al. (2016), 1.9 to $2.8 \% / \mathrm{h}$ (depending on the measurement method and regression model). In situ rates of pdNDFD observed in the current study were also lower compared with rates for corn silage NDF determined IS (Weisbjerg et al., 2007) or reported for an IV system by Raffrenato et al. (2019). These discrepancies among studies are likely caused by different maturities of the corn silages and differences in the analytical methods used. A similarly low IS rate of degradation $(1.0 \% / \mathrm{h})$ of corn silage total NDF has been reported in another study from our laboratory (Harper et al., 2018) and by Hatew et al. (2016). As clearly shown in Hatew et al. (2016), the IS rate of NDFD of corn silage linearly decreases with increasing plant maturity (in their study, from 1.7 to $1.2 \%$ / h for corn silage harvested at 25 to $40 \%$ DM content).

\section{Effect of Ensiling Time on NDF Degradability Variables}

Chemical composition and IS and NIR NDFD of the corn silage samples, as affected by ensiling time, are shown in Table 2 and Figure 1. Concentrations of NDF and ADF (wet chemistry analysis; CVAS) or estimated pdNDF were not affected by ensiling time. Concentration of NDICP decreased $(P<0.001)$ quadratically with ensiling time. The ratio of ADF $\div$ NDF increased quadratically $(P<0.001)$, and the corresponding (estimated) hemicellulose concentration decreased quadratically $(P=0.008)$ with ensiling time. Lignin concentration on DM basis and as a percentage of NDF linearly increased $(P \leq 0.03)$ with increasing silage ensiling time. We found no interactions $(P \geq$ 0.80 ) between hybrid and ensiling time for any of the variables analyzed.

Little degradation (disappearance from the bag) of silage total NDF occurred up to $12 \mathrm{~h}$ of rumen incubation (Figure 1), but at $72 \mathrm{~h}$ over $75 \%$ of pdNDF was degraded (Table 2). With increasing ensiling time from 0 to $150 \mathrm{~d}$, ISpdRate decreased $(P=0.007)$ linearly and were about 14 to $15 \%$ lower for the 150 -d silages compared with the unfermented silage $(0 \mathrm{~d})$. Ruminal ISpdED decreased $(P \leq 0.008)$ linearly with increasing ensiling time. Compared with unfermented silage, the 150-d silages had 5.3 percentage units lower ISpdED. In situ pdNDFD at $24 \mathrm{~h}$ tended to decrease quadratically $(P \leq 0.08)$ with increasing ensiling time. In situ pdNDFD at $72 \mathrm{~h}$ followed the same trend $(P=0.02)$ as those of $24-$ and $48-\mathrm{h}$ incubations. Indigestible NDF at $288 \mathrm{~h}$ was not affected by ensiling time. Analyses of NDFD using NIR methods (sNDFD30, TTNDFD, and NDFD30) generally followed trends similar to the IS data (Table 2). Overall, ensiling time decreased 
NIR NDFD measurements quadratically $(P \leq 0.007)$, whereas the effect appeared to be mostly linear when the IS method was used.

Reports on the effect of ensiling time on corn silage NDFD have been inconsistent. Sanderson (1993) and Hunt et al. (1993) reported no effect of ensiling time (40 vs. $186 \mathrm{~d}$ and 0 vs. $60 \mathrm{~d}$, respectively) on corn silage short-term IS and IV NDF digestibility. A similar lack of effect of ensiling time on 30-h IV NDF degradability was also reported by Der Bedrosian et al. (2012; ensiling times of 45 and $270 \mathrm{~d}$ ) and Ferraretto et al. (2015; ensiling time of 0 to $240 \mathrm{~d}$ ). Cherney et al. (2007), however, reported about 7 percentage units decrease in IV NDFD of corn silage hybrids ensiled for $30 \mathrm{~d}$ and a 2.7 percentage units decrease of NDFD30 (by IV) after $150 \mathrm{~d}$ of ensiling was also reported by Young et al. (2012). Overall, the effect of ensiling time on ISpdED in the current study corresponded well to the changes observed in the chemical composition of the silages, specifically disappearance (due to silage fermentation) of hemicellulose, which is the most digestible fraction of the major plant cell-wall constituents (Smith et al.,
1972). Protein bound to NDF (NDICP) also decreased with ensiling time, particularly in the initial $30 \mathrm{~d}$, and contributed to the decreased silage ISpdED. A similar decrease in NDICP in silage compared with the original crop was reported by Bakken et al. (2011), reflecting protein degradation during the ensiling process.

The effect of ensiling time on total lignin and structural cell-wall carbohydrates (following starch extraction) of 3 of the corn silage hybrids is shown in Appendix Table A1. Ensiling time did not have an effect $(P \geq$ 0.19 ) on cell-wall carbohydrates, but several significant differences among hybrids occurred. Total lignin was higher $(P \leq 0.01)$ for MC relative to HHG, with HUB1 being intermediate. With respect to the structural carbohydrates, the MC variety had higher glucan and lower galactan values than the other hybrids $(P=0.009$ and $P=0.006$, respectively), whereas xylan concentration was lowest $(P \leq 0.001)$ for the HHG variety. No hybrid $x$ ensiling time interactions were found for any of the cell-wall carbohydrates $(P \geq 0.18)$, except for arabinan $(P<0.001)$. The interaction for arabinan was caused by $(1)$ higher $(P=0.008)$ arabinan concentration for

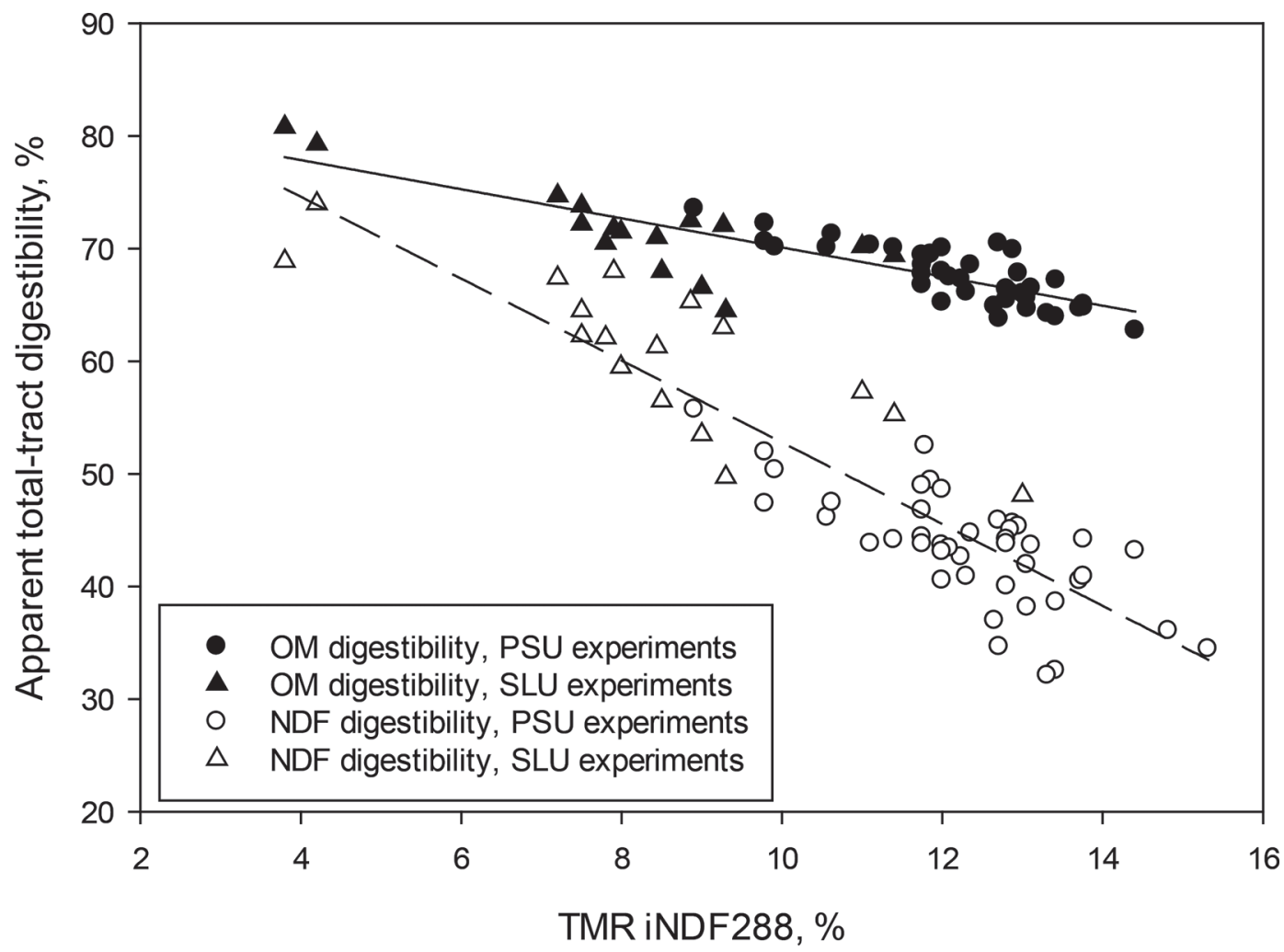

Figure 3. Relationship between 288-h in situ indigestible NDF (iNDF288, \% of DM) concentration in TMR samples and apparent totaltract digestibility (ATTD) of OM and NDF from experiments with lactating dairy cows conducted at The Pennsylvania State University (PSU, University Park, PA; 12 experiments) and the Swedish University of Agricultural Sciences (SLU, Umeå, Sweden; 4 experiments). Individual cow data were averaged per treatment within experiment. ATTD of OM $(\%)=83.0(\mathrm{SE}=1.23)-1.29(\mathrm{SE}=0.109) \times \mathrm{TMR}$ iNDF288 $[\%$; $=58$; $\mathrm{R}^{2}=0.72 ;$ root mean square error $\left.(\mathrm{RMSE})=1.92 ; P<0.001\right) ;$ ATTD of NDF $(\%)=89.1(\mathrm{SE}=2.69)-3.63(\mathrm{SE}=0.235) \times \mathrm{TMR}$ iNDF288 $\left(\% ; \mathrm{n}=59 ; \mathrm{R}^{2}=0.80 ; \mathrm{RMSE}=4.36 ; P<0.001\right)$. 


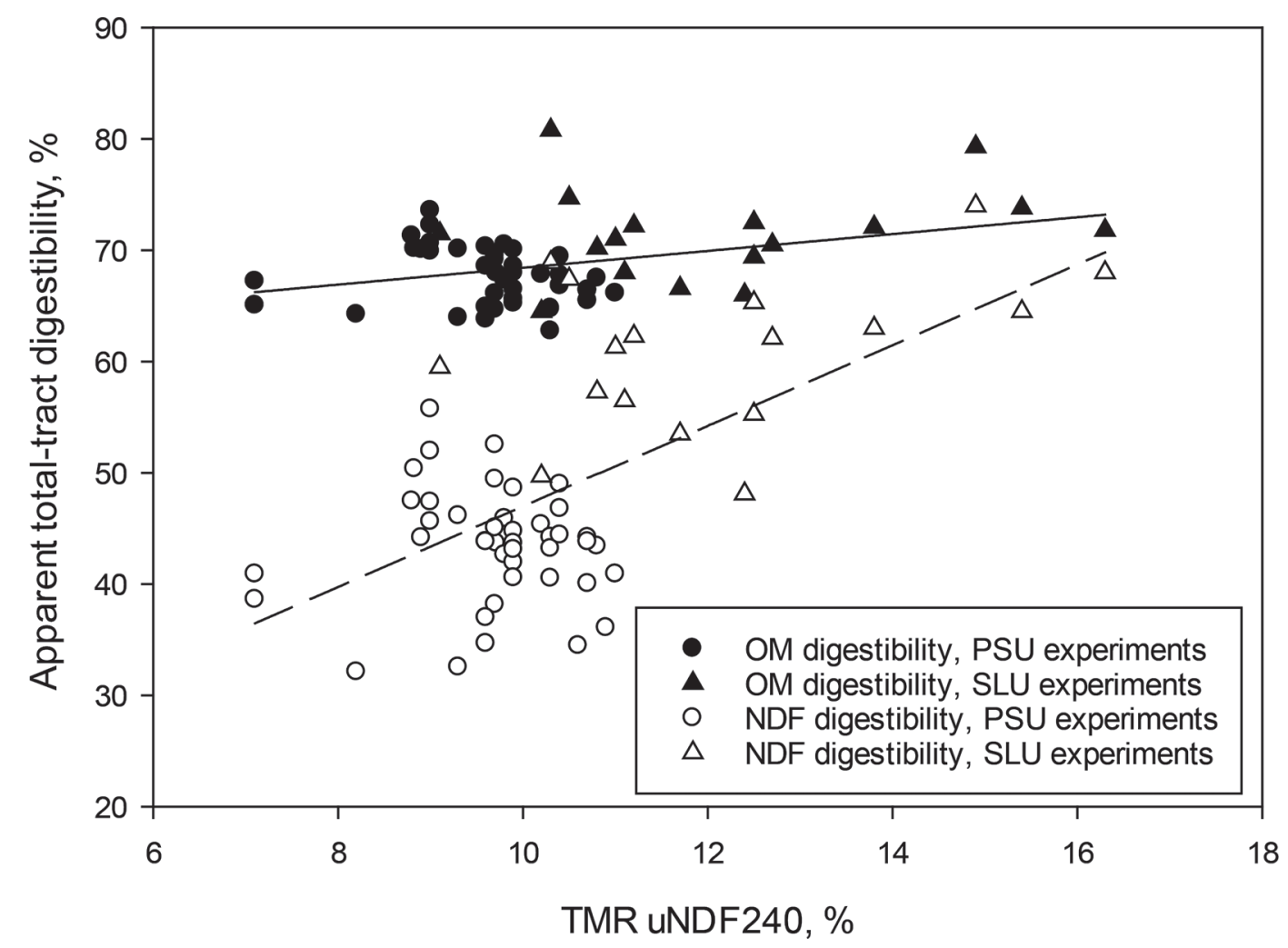

Figure 4. Relationship between near-infrared reflectance spectroscopy (NIR) undegraded NDF (uNDF240, \% of DM) concentration in TMR samples and apparent total-tract digestibility (ATTD) of OM and NDF from experiments with lactating dairy cows conducted at The Pennsylvania State University (PSU, University Park, PA; 12 experiments) and the Swedish University of Agricultural Sciences (SLU, Umeå, Sweden; 4 experiments). Individual cow data were averaged per treatment within experiment. ATTD of OM $(\%)=60.9(\mathrm{SE}=2.74)+0.76(\mathrm{SE}$ $=0.261) \times \mathrm{TMR} u N D F 240\left[\% ; \mathrm{n}=58 ; \mathrm{R}^{2}=0.13 ;\right.$ root mean square error $\left.(\mathrm{RMSE})=3.37 ; P=0.005\right] ; \mathrm{ATTD}$ of NDF $(\%)=10.3(\mathrm{SE}=6.27)$ $+3.63(\mathrm{SE}=0.595) \times \mathrm{TMR}$ uNDF240 $\left(\% ; \mathrm{n}=60 ; \mathrm{R}^{2}=0.39 ; \mathrm{RMSE}=7.70 ; P<0.001\right)$.

HUB1 and HHG (5.02 and 5.32\%, respectively) than for MC (4.87\%) at $0 \mathrm{~d}$ ensiling time; (2) no difference $(P=0.17)$ between HUB1 and MC (5.16 and 4.90\%, respectively) and lower (4.41\%) concentration for HHG $(P \leq 0.03)$ compared with the other 2 hybrids at $30 \mathrm{~d}$; and $(3)$ higher $(P=0.03)$ arabinan concentration for $\mathrm{MC}$ than for HHG (5.05 and $4.55 \%$, respectively), and lack of data for HUB1 at $120 \mathrm{~d}$. Although the lower lignin in HHG would normally be expected to increase digestibility, this hybrid also had a lower level of structural carbohydrates than HUB1 or MC (by $>2 \%$ and almost $4 \%$ of $\mathrm{DM}$, respectively). With less digestible energy from carbohydrates available, the benefit of the lower lignin for silage digestibility was likely decreased.

\section{Relationship Among In Situ and Laboratory Fiber Analyses}

Correlation coefficients for the relationship of IS pdNDFD variables with laboratory fiber-related NIR analyses commonly reported for corn silage are shown in Table 3. The correlations were generally weak to moderate. In situ rates of pdNDFD or ISpdED were not correlated with NDF or lignin concentrations (both LabA and LabB), sNDFD30 and TTNDFD (LabA) and NDFD30 (LabB), and moderately $(P=0.05$ to $<0.01$ ) correlated with pdNDFD240 (LabA) and uNDF240 and kdNDF (LabB). Correlation of ISpdRate with estimated kdNDFLabA was nonexistent $(-0.13$ at $P=0.27$; data not presented in tables). Similar correlation coefficients were observed for the individual IS pdNDFD rumen incubation time points. Concentration of IS iNDF288 was moderately correlated with NDF and lignin concentrations (both LabA and LabB; $P$ $\leq 0.001$ ). The correlation of IS iNDF288 with LabA fiber degradability analyses was relatively weak $(P$ $=0.07$ with pdNDFD240) or nonexistent (sNDFD30 and TTNDFD). Correlation of IS iNDF288 with LabB uNDF240 was moderately strong $(P \leq 0.001)$. Correlation of IS iNDF288 with lignin was moderately high ( $\mathrm{r}$ 
$=0.37$ to $0.48, P \leq 0.001$ ), but IS iNDF288 did not correlate with uNDFLabA $(\mathrm{r}=0.22, P=0.06$; data not published in table).

Bender et al. (2016) compared IS and IV methods (and 2 fermentation end points, 120 and $288 \mathrm{~h}$ ) to estimate iNDF of 13 corn silage samples and reported that the highest iNDF values (32.1\% of NDF) were determined with 120-h IV incubation and the lowest (25.7\%; i.e., highest NDF digestibility) were found with 288 -h IS incubation (IS iNDF288). In that study, within incubation time, estimated TTNDFD was similar among silages, whereas uNDF values, derived from different approaches (IS vs. IV), were significantly different. Unlike data from the current study, Raffrenato et al. (2018) reported a considerably better relationship $\left(\mathrm{R}^{2}\right.$
$=0.89$ ) between uNDF analyzed by a $240-\mathrm{h}$ IV (i.e., uNDF240) vs. a 384 -h IS procedure. The duration of IS incubation in their study was longer (by $96 \mathrm{~h}$ ) than the IS approach used in the current study, but it is unlikely that this is the reason for the observed discrepancy between the 2 studies. The most likely explanation for the different relationship of uNDF240 and IS iNDF in these studies is that uNDF240 in our experiment was determined by NIR, whereas a wet chemistry method was used in Raffrenato et al. (2018). It is also worth pointing out that very little degradability or disappearance of NDF occurs after 200-h IS incubation (as seen in Figure 1 of the current study and Figure 1 in Raffrenato et al., 2018, which shows NDF residue of 12 forages after IV fermentation from 12 to 504 h). Earlier,

Table 2. Effect of hybrid $(\mathrm{H})^{1}$ and ensiling time (ET) on corn silage fiber fractions and NDF degradability

\begin{tabular}{|c|c|c|c|c|c|c|c|c|}
\hline Variable & \multicolumn{5}{|c|}{ Days ensiled } & SEM & \multicolumn{2}{|c|}{$P$-value ${ }^{2}$} \\
\hline \multicolumn{9}{|l|}{ Chemical analyses ${ }^{3}$} \\
\hline pdNDF, $\%$ of DM & 26.7 & 25.9 & 26.8 & 26.8 & 26.4 & 0.52 & 0.006 & 0.68 \\
\hline NDICP, $\%$ of DM & 1.11 & 0.90 & 0.87 & 0.87 & 0.87 & 0.023 & 0.19 & $<0.001(\mathrm{Q})$ \\
\hline $\mathrm{ADF}, \%$ of $\mathrm{DM}$ & 20.9 & 21.0 & 21.8 & 22.3 & 21.8 & 0.50 & 0.006 & $0.17(\mathrm{~L})^{4}$ \\
\hline Lignin, $\%$ of DM & 2.61 & 2.61 & 2.65 & 2.76 & 2.81 & 0.055 & $<0.001$ & $0.03(\mathrm{~L})$ \\
\hline Lignin, $\%$ of NDF & 6.87 & 6.99 & 7.08 & 7.28 & 7.46 & 0.106 & 0.03 & $0.001(\mathrm{~L})$ \\
\hline \multicolumn{9}{|l|}{ In situ ${ }^{5}$} \\
\hline ISpdRate, \%/h & 2.09 & 1.97 & 1.70 & 1.73 & 1.78 & 0.095 & 0.23 & $0.007(\mathrm{~L})$ \\
\hline ISpdED, $\%$ & 51.4 & 48.9 & 46.6 & 46.7 & 46.1 & 1.45 & 0.17 & $0.008(\mathrm{~L})$ \\
\hline ISpdNDFD24, \% & 32.6 & 27.5 & 24.1 & 27.8 & 26.3 & 2.46 & 0.39 & $0.07(\mathrm{Q})$ \\
\hline ISpdNDFD48, \% & 66.5 & 64.6 & 58.7 & 57.4 & 57.3 & 2.48 & 0.39 & $0.002(\mathrm{~L})$ \\
\hline TTNDFD, \% (LabA) & 38.3 & 33.9 & 33.0 & 30.8 & 34.1 & 1.42 & 0.78 & $0.007(\mathrm{Q})$ \\
\hline uNDF240DM, \% (LabB) & 7.78 & 9.20 & 9.34 & 9.58 & 9.78 & 0.310 & 0.002 & $0.02(\mathrm{Q})$ \\
\hline NDFD30, \% (LabB) & 62.0 & 58.0 & 57.6 & 56.8 & 56.2 & 0.57 & 0.001 & $0.001(\mathrm{Q})$ \\
\hline
\end{tabular}

${ }^{1}$ The following hybrids were included in the study: Hubner H5333RC3P, H6191RCSS, and H5222RC3P (Hubner Seed, Monticello, IN); Masters Choice MC 5250 (Masters Choice, Anna, IL); and Healthy Herd Genetics 42HFC15 (Healthy Herd Genetics and Nutrition, Greenport, NY).

${ }^{2}$ Effects of corn silage hybrid $(\mathrm{H})$ and ensiling time $(\mathrm{ET} ; \mathrm{L}=$ linear; $\mathrm{Q}=$ quadratic). No hybrid $\times$ ensiling time interaction was found for any of the variables $(P \geq 0.80)$; largest SEM presented; $\mathrm{n}=74$.

${ }^{3}$ Chemical analyses: NDF and ADF analyzed by wet chemistry methods (on separate samples), pdNDF = potentially degradable NDF, estimated as NDF - iNDF288DM; NDICP (neutral detergent insoluble CP) and lignin (as \% of DM or NDF) analyzed by NIR methods (Cumberland Valley Analytical Services, Waynesboro, PA); hemicellulose = NDF - ADF, \% of DM.

${ }^{4} P_{\text {Linear }}=0.03$.

${ }^{5}$ In situ NDF degradability data from The Pennsylvania State University. ISpdRate = rate of in situ degradation of potentially degradable $\mathrm{NDF}, \% / \mathrm{h}$; ISpdED = in situ effective ruminal degradability of potentially degradable NDF, estimated at $2 \% / \mathrm{h}$ passage rate, $\%$ of NDF; ISpdNDFD24, ISpdNDFD48, and ISpdNDFD72 = in situ 24-, 48-, and 72-h degradability of potentially degradable NDF, respectively, \% of NDF; iNDF288 = 288-h in situ indigestible NDF, \% of NDF; iNDF288DM $=288$-h in situ indigestible NDF, \% of DM.

${ }^{6}$ In vitro NDF degradability data from near-infrared reflectance spectroscopy (NIR) analyses at LabA (Rock River Laboratories Inc., Watertown, WI) and LabB (Cumberland Valley Analytical Services). sNDFD30 = standardized NDF degradability at 30 h, \% of NDF (Goeser et al., 2009); TTNDFD = total-tract NDF digestibility, \% of NDF (Combs, 2013; Lopes et al., 2015); uNDF240DM = undegraded NDF at 240 h, \% of DM; NDFD30 $=$ NDF degradability at $30 \mathrm{~h}, \%$ of NDF. 
Table 3. Pearson correlation coefficients of in situ (IS) pdNDF degradability variables with selected near-infrared reflectance spectroscopy (NIR) analyses from 2 commercial laboratories of corn silage hybrids ensiled for 0 to $150 \mathrm{~d}(\mathrm{n}=73)^{1}$

\begin{tabular}{|c|c|c|c|c|c|c|}
\hline NIR fiber analyses ${ }^{2}$ & ISpdRate & ISpdED & ISpdNDFD24 & ISpdNDFD48 & ISpdNDFD72 & iNDF288 \\
\hline aNDF & -0.05 & -0.09 & $<0.01$ & -0.06 & $-0.20(0.10)$ & $0.41(<0.001)$ \\
\hline pdNDFD240 & $0.30(<0.01)$ & $0.30(<0.01)$ & $0.25(0.03)$ & $0.28(0.02)$ & 0.12 & $0.22(0.07)$ \\
\hline TTNDFD & 0.03 & $<0.01$ & 0.09 & -0.01 & -0.07 & -0.12 \\
\hline \multicolumn{7}{|l|}{ LabB } \\
\hline NDFD30 & 0.19 & 0.17 & $0.22(0.07)$ & $0.21(0.08)$ & 0.02 & 0.16 \\
\hline uNDF240 & $-0.24(0.04)$ & $-0.23(0.05)$ & -0.11 & $-0.25(0.03)$ & $-0.26(0.03)$ & $0.40(<0.001)$ \\
\hline kdNDF & $0.31(<0.01)$ & $0.32(<0.01)$ & $0.21(0.08)$ & $0.35(<0.01)$ & $0.26(0.03)$ & $-0.24(0.04)$ \\
\hline
\end{tabular}

${ }^{1}$ The following hybrids were included in the study: Hubner H5333RC3P, H6191RCSS, and H5222RC3P (Hubner Seed, Monticello, IN); Masters Choice MC 5250 (Masters Choice, Anna, IL); and Healthy Herd Genetics 42HFC15 (Healthy Herd Genetics and Nutrition, Greenport, NY). Data are correlation coefficients $(\mathrm{r})$ with $P$-values in parentheses; when lacking, the correlation was nonsignificant, $P \geq 0.25$.

${ }^{2}$ pdNDF $=$ potentially degradable NDF, $\%$ of DM; ISpdRate = rate of in situ degradation of potentially degradable NDF (see Materials and Methods), $\% / \mathrm{h}$; ISpdED = in situ effective ruminal degradability of potentially degradable NDF, estimated at $2 \% / \mathrm{h}$ passage rate, $\%$ of NDF; ISpdNDFD24, ISpdNDFD48, and ISpdNDFD72 = in situ 24-, 48-, and 72-h degradability of potentially degradable NDF, respectively, \% of NDF; iNDF288 = 288-h in situ indigestible NDF, \% of DM; LabA = Rock River Laboratories Inc. (Watertown, WI); LabB = Cumberland Valley Analytical Services (Waynesboro, PA); aNDF and aNDFom = amylase-treated NDF and amylase-treated NDF on an ash-free basis, respectively, $\%$ of DM; lignin = lignin, $\%$ of DM; sNDFD30 = standardized NDF degradability at $30 \mathrm{~h}, \%$ of NDF (Goeser et al., 2009); pdNDFD240 = potentially degradable NDF at 240 h, \% of NDF (Lopes et al., 2015); TTNDFD = total-tract NDF digestibility, \% of NDF (Combs, 2013; Lopes et al., 2015); NDFD30 = NDF degradability at $30 \mathrm{~h}, \%$ of NDF; uNDF240 = undegraded NDF at $240 \mathrm{~h}, \%$ of DM (of NDF); and kdNDF = rate of NDF degradation, as determined by Cumberland Valley Analytical Services, based on Van Amburgh et al. (2003), \%/h.

Traxler et al. (1998) also reported that NDF digestibility was not significantly different between 144- and 192-h IV incubation.

We discovered good relationships between uNDF240 (\% of DM) and lignin concentration and NDFD30 $\left(\mathrm{R}^{2}\right.$ $=0.73$ and 0.88 , respectively; $P<0.001$ ) for the corn silage samples analyzed by LabB using NIR methods in this study (Figure 2). The relationship of uNDF240 and lignin is not surprising. Lignin and lignification of plants have been long associated with decreased digestibility of cell-wall constituents (Van Soest, 1967), and lignin is used by current feeding models to predict NDF digestibility (e.g., NRC, 2001). Traxler et al. (1998) reported high correlations $(\mathrm{r}>0.81)$ between 144-h IV iNDF and lignin concentrations for a wide range of forage species. The relationship between uNDF240 and NDFD30 makes sense, as fiber digestibility is expected to decrease with increasing lignification. Compared with IS NDFD, the lag time for NDFD in the traditional IV procedure (Goering and Van Soest, 1970), used for NIR NDFD30 calibration by LabB, appears to be short (1 to $3 \mathrm{~h}$; Raffrenato et al., 2019) and would also contribute to the close relationship between NDFD30 and uNDF240. An examination of partial data for the 2017 and 2018 corn silage hybrids participating in PSUCSTP showed similarly high relationships between NIR uNDF240 and NDFD30 analyses $\left(\mathrm{R}^{2}=0.95, \mathrm{n}=107\right.$, and $\mathrm{R}^{2}=0.80, \mathrm{n}=127$, respectively; data not shown).

\section{Relationship Between iNDF288 and uNDF240 and In Vivo Total-Tract NDF Digestibility}

In an attempt to relate iNDF288 and uNDF240 to in vivo ATTD of OM and NDF, we analyzed data from 16 experiments with lactating dairy cows (Table 4). The relationship between iNDF288 and ATTD of OM and NDF was good, with $\mathrm{R}^{2}=0.72$ and 0.80 , respectively, and root mean squared error (RMSE) of 1.92 and 4.36, respectively (Figure 3). In contrast, however, the relationships between uNDF240 (NIR analysis by LabB) and in vivo ATTD of $\mathrm{OM}$ and $\mathrm{NDF}$ were poor $\left(\mathrm{R}^{2}=\right.$ 0.13 and $0.39 ; \mathrm{RMSE}=3.37$ and 7.70 , respectively; $P$ $\leq 0.005)$ and, surprisingly, positive (Figure 4). When only PSU data (i.e., corn silage-based TMR) were considered, we found no relationship between uNDF240 and in vivo ATTD of NDF $\left(\mathrm{R}^{2} \leq 0.04 ; P \geq 0.21\right.$; data not shown), whereas the relationships of iNDF288 with ATTD of OM and NDF were moderate to high $\left(\mathrm{R}^{2}\right.$ $=0.69$ and 0.51 , respectively; $P \leq 0.005$; data not shown). In one of the studies from the PSU data set, in vivo ATTD was determined by total fecal collection (Räisänen et al., 2018). When only these data $(\mathrm{n}=5)$ were used, the relationships with ATTD of OM and NDF were $\mathrm{R}^{2}=0.43$ and $0.71(P \geq 0.07$; RMSE of 1.19 and 2.17), respectively (for iNDF288), and 0.30 and 0.21 ( $P \geq 0.34$; RMSE of 1.32 and 3.58), respectively (for uNDF240). 
Table 4. Descriptive statistics of total-tract apparent digestibility data from experiments with lactating dairy cows conducted at The Pennsylvania State University (PSU; University Park, PA) and at the Swedish University of Agricultural Sciences (SLU; Umeå, Sweden)

\begin{tabular}{|c|c|c|c|c|c|c|c|c|c|}
\hline Site $^{1}$ & Variable $^{2}$ & $\mathrm{~N}^{3}$ & Mean & $\mathrm{SD}$ & Minimum & Maximum & $\mathrm{CV}$ & $\begin{array}{c}\text { Lower } \\
95 \% \mathrm{CL} \\
\text { for mean }\end{array}$ & $\begin{array}{c}\text { Upper } \\
95 \% \mathrm{CL} \\
\text { for mean }\end{array}$ \\
\hline \multirow[t]{4}{*}{$\overline{\mathrm{PSU}}$} & DMI, $\mathrm{kg} / \mathrm{d}$ & 46 & 27.1 & 1.73 & 23.8 & 31.5 & 6.4 & 26.5 & 27.6 \\
\hline & ATTD of OM, \% & 41 & 67.6 & 2.56 & 62.8 & 73.6 & 3.8 & 66.8 & 68.4 \\
\hline & ATTD of NDF, $\%$ & 43 & 43.4 & 5.15 & 32.1 & 55.7 & 11.9 & 41.9 & 45.0 \\
\hline & iNDF $288, \%$ & 46 & 12.3 & 1.30 & 8.9 & 15.3 & 10.6 & 11.9 & 12.7 \\
\hline \multirow{5}{*}{ SLU } & Milk yield, $\mathrm{kg} / \mathrm{d}$ & 13 & 27.7 & 1.43 & 24.9 & 29.7 & 5.2 & 26.8 & 28.6 \\
\hline & ATTD of OM, \% & 17 & 71.5 & 4.24 & 64.5 & 80.8 & 5.9 & 69.3 & 73.6 \\
\hline & ATTD of NDF, $\%$ & 17 & 61.0 & 6.97 & 48.1 & 74.0 & 11.4 & 57.4 & 64.6 \\
\hline & iNDF288, \% & 17 & 8.4 & 2.26 & 3.8 & 13.0 & 26.9 & 7.2 & 9.6 \\
\hline & uNDF $240, \%$ & 17 & 12.1 & 1.99 & 9.1 & 16.3 & 16.4 & 11.1 & 13.2 \\
\hline
\end{tabular}

${ }^{1} \mathrm{PSU}=12$ experiments; SLU $=4$ experiments.

${ }^{2}$ ATTD of OM = apparent total-tract OM digestibility, \% of OM; ATTD of NDF = apparent total-tract NDF digestibility, \% of NDF; iNDF288 $=$ indigestible NDF (288-h in situ rumen incubation), \% of DM; uNDF240 = undegraded NDF at $240 \mathrm{~h}, \%$ of DM (near-infrared reflectance spectroscopy analysis by Cumberland Valley Analytical Services, Waynesboro, PA).

${ }^{3} \mathrm{n}=$ number of treatment means used in the statistical analysis; CL = confidence limit.

The lack of relationship between uNDF240 (as analyzed by NIR in the current study) and ATTD of OM or NDF digestibility is somewhat surprising. If properly calibrated, NIR can be successfully used to predict iNDF (or its modification, uNDF240; Raffrenato et al., 2018) concentration in forages (Nousiainen et al., 2004; Krizsan et al., 2014), and a good relationship between uNDF240 (determined IV) and lignin content was reported for a wide variety of forages by Palmonari et al. (2016).

The notion that undigested forage residues, in feces or in IV residues, are primarily composed of plant cellwall materials has been known for decades (Van Soest et al., 1966), and long-term (5- to 6-d) IV or IS incubations have been used to characterize forage fiber in ruminant diets (Wilkins, 1969; Goering and Van Soest, 1970). Lippke (1986) proposed a 144-h IV incubation to determine NDF digestibility of ryegrass and sorghum forages, which the author termed "indigestible NDF" and suggested that maximum iNDF consumption is about $20 \mathrm{~g} / \mathrm{kg}$ of metabolic BW. The procedure was based on the principle of IV incubations with ruminal fluid, as outlined by Goering and Van Soest (1970). Indigestible NDF has been recommended as an intrinsic digestibility marker (Huhtanen et al., 1994; Lee and Hristov. 2013; Morris et al., 2018), and 120-h IV iNDF has been shown to predict well nutrient digestibility and lactational performance of dairy cows in commercial farm settings (Schalla et al., 2012). Grass silage ash-free iNDF288 concentration was closely related to in vivo ATTD of OM, determined by total fecal collection, for 86 silages (Huhtanen et al., 2005). In that study, the relationship of iNDF288 with ATTD of OM was more uniform for different forage types than the relationship with an IV pepsin-cellulase method. The current study demonstrated a poor relationship of uNDF240 (analyzed by NIR methods) and ATTD of $\mathrm{OM}$ or $\mathrm{NDF}$, and, based on these limited observations, it can be concluded that NIR uNDF240 of TMR samples cannot be used to accurately predict in vivo digestibility of dietary NDF. In contrast, the relationship of iNDF288 with in vivo ATTD of NDF was high across studies with lactating dairy cows and appears to be a reliable marker for in vivo digestibility of NDF.

\section{CONCLUSIONS}

In this study, in situ degradability of silage NDF linearly decreased from 0 to $150 \mathrm{~d}$ ensiling time, primarily caused by quadratic decreases in hemicellulose and NDF-bound CP concentrations. These results suggest that rumen NDF degradability of corn silage hybrids should be evaluated following ensiling for at least 30 d. The correlation of IS pdNDF degradability measurements with common laboratory NIR NDF-related analyses was poor to moderate. This suggests that laboratory NIR techniques may be reliable for evaluating the chemical composition of corn silage but may lack accuracy in assessing rumen degradability of silage NDF. In support of this, we found a good relationship between dietary concentration of iNDF288 and in vivo apparent total-tract TMR NDF digestibility from 16 experiments with lactating dairy cows, but the relationship with uNDF240 was poor or nonexistent. This 
analysis suggests that uNDF240, as analyzed by NIR, cannot be used to predict in vivo OM or NDF digestibility and, likely, lactational performance of dairy cows.

\section{ACKNOWLEDGMENTS}

This work was supported by the USDA National Institute of Food and Agriculture Federal Appropriations under Project PEN 04539 and Accession number 1000803 (Washington, DC). Partial financial support for the study by the Professional Dairy Managers of Pennsylvania (Harrisburg, PA) and Cargill Animal Nutrition (Shippensburg, PA) is acknowledged. The authors thank Cumberland Valley Analytical Services (Waynesboro, PA) and Rock River Laboratories (Watertown, WI) for analyzing the samples from the project, and the staff of The Pennsylvania State University's Dairy Teaching and Research Center (University Park, PA) for their conscientious care of the cows used in the IS experiment. The authors have not stated any conflicts of interest.

\section{REFERENCES}

Bakken, A. K., Å. T. Randby, and P. Udén. 2011. Changes in fibre content and degradability during preservation of grass-clover crops. Anim. Feed Sci. Technol. 168:122-130. https://doi.org/10 .1016/j.anifeedsci.2011.03.016.

Bender, R. W., D. E. Cook, and D. K. Combs. 2016. Comparison of in situ versus in vitro methods of fiber digestion at 120 and 288 hours to quantify the indigestible neutral detergent fiber fraction of corn silage samples. J. Dairy Sci. 99:5394-5400. https://doi.org/ $10.3168 / j d s .2015-10258$.

Cabezas-Garcia, E. H., S. J. Krizsan, K. J. Shingfield, and P. Huhtanen. 2017. Effects of replacement of late-harvested grass silage and barley with early-harvested silage on milk production and methane emissions. J. Dairy Sci. 100:5228-5240. https://doi.org/10.3168/ jds.2016-12444.

Cherney, D. J. R., J. H. Cherney, and W. J. Cox. 2007. Forage quality differences of corn hybrids as influenced by ensiling. Forage Grazinglands 5:0. https://doi.org/10.1094/FG-2007-0918-01-RS.

Combs, D. K. 2013.TTNDFD: A new approach to evaluate forages. Pages 113-125 in Proc. 2013 Cornell Nutrition Conf. Dept. Anim. Sci., Cornell Univ., Ithaca, NY.

Der Bedrosian, M. C., K. E. Nestor Jr., and L. Kung Jr.. 2012. The effects of hybrid, maturity, and length of storage on the composition and nutritive value of corn silage. J. Dairy Sci. 95:5115-5126. https://doi.org/10.3168/jds.2011-4833.

Essien, D., and T. L. Richard. 2018. Wet ensiled storage accelerates pretreatment for bioconversion of corn stover. Front. Bioeng. Biotechnol. 6:195. https://doi.org/10.3389/fbioe.2018.00195.

Ferraretto, L. F., R. D. Shaver, S. Massie, R. Singo, D. M. Taysom, and J. P. Brouillette. 2015. Effect of ensiling time and hybrid type on fermentation profile, nitrogen fractions, and ruminal in vitro starch and neutral detergent fiber digestibility in whole-plant corn silage. Prof. Anim. Sci. 31:146-152. https://doi.org/10.15232/pas .2014-01371.

Giallongo, F., J. Oh, T. Frederick, B. Isenberg, D. M. Kniffen, A. N. Hristov, and R. A. Fabin. 2015. Extruded soybean meal increased feed intake and milk production in dairy cows. J. Dairy Sci. 98:6471-6485. https://doi.org/10.3168/jds.2015-9786.

Giallongo, F., M. Harper, J. Oh, J. Lopes, H. Lapierre, R. A. Patton, C. Parys, I. Shinzato, and A. N. Hristov. 2016. Effects of rumen-protected methionine, lysine and histidine on lactation performance of dairy cows. J. Dairy Sci. 99:4437-4452. https://doi .org/10.3168/jds.2015-10822.

Giallongo, F., M. T. Harper, J. Oh, C. Parys, I. Shinzato, and A. N. Hristov. 2017. Histidine deficiency has a negative effect on lactational performance of dairy cows. J. Dairy Sci. 100:2784-2800. https://doi.org/10.3168/jds.2016-11992.

Goering, H. K., and P. J. Van Soest. 1970. Forage fiber analyses. USDA Agricultural Handbook No. 379. US Government Printing Office, Washington, DC.

Goeser, J. P., P. C. Hoffman, and D. K. Combs. 2009. Modification of a rumen fluid priming technique for measuring in vitro neutral detergent fiber digestibility. J. Dairy Sci. 92:3842-3848. https:// doi.org/10.3168/jds.2008-1745.

Harper, M., J. Oh, F. Giallongo, J. C. Lopes, G. W. Roth, and A. N. Hristov. 2017a. Using brown midrib dwarf forage sorghum silage and fall grown oat silage in lactating dairy cow rations. J. Dairy Sci. 100:5250-5265. https://doi.org/10.3168/jds.2017-12552.

Harper, M., J. Oh, F. Giallongo, G. W. Roth, and A. N. Hristov. $2017 \mathrm{~b}$. Inclusion of wheat and triticale silage in the diet of lactating dairy cows. J. Dairy Sci. 100:6151-6163. https://doi.org/10 .3168/jds.2017-12553.

Harper, M., G. Roth, H. L. Wells, C. Canale, A. Gallo, F. Masoero, and A. N. Hristov. 2016. In vitro starch and neutral-detergent fiber degradability of corn silage hybrids. J. Dairy Sci. 99(E-Suppl. 1):687.

Harper, M. T., A. Melgar, J. Oh, K. Nedelkov, G. Sanchez, G. W. Roth, and A. N. Hristov. 2018. Inclusion of brown midrib dwarf pearl millet silage in the diet of lactating dairy cows. J. Dairy Sci 101:5006-5019. https://doi.org/10.3168/jds.2017-14036.

Harper, M. T., J. Oh, A. Melgar, K. Nedelkov, S. Räisänen, X. Chen, C. M. M. R. Martins, M. Young, T. L. Ott, D. M. Kniffen, R. A. Fabin, and A. N. Hristov. 2019. Production effects of feeding extruded soybean meal to early-lactation dairy cows. J. Dairy Sci. 102:8999-9016. https://doi.org/10.3168/jds.2019-16551.

Hatew, B., A. Bannink, H. van Laar, L. H. de Jonge, and J. Dijkstra. 2016. Increasing harvest maturity of whole-plant corn silage reduces methane emission of lactating dairy cows. J. Dairy Sci. 99:354-368. https://doi.org/10.3168/jds.2015-10047.

Hristov, A. N., W. Hazen, and J. W. Ellsworth. 2006. Efficiency of use of imported nitrogen, phosphorus, and potassium and potential for reducing phosphorus imports on Idaho dairy farms. J. Dairy Sci 89:3702-3712. https://doi.org/10.3168/jds.S0022-0302(06)72411 $-0$.

Huhtanen, P., K. Kaustell, and S. Jaakkola. 1994. The use of internal markers to predict total digestibility and duodenal flow of nutrients in cattle given six different diets. Anim. Feed Sci. Technol. 48:211-227. https://doi.org/10.1016/0377-8401(94)90173-2.

Huhtanen, P., J. Nousiainen, and M. Rinne. 2005. Prediction of silage composition and organic matter digestibility from herbage composition and pepsin-cellulase solubility. Agric. Food Sci. 14:154-165. https://doi.org/10.2137/145960605774826046.

Hunt, C. W., W. Kezar, D. D. Hinman, J. J. Combs, J. A. Loesche, and T. Moen. 1993. Effects of hybrid and ensiling with and without a microbial inoculant on the nutritional characteristics of whole-plant corn. J. Anim. Sci. 71:38-43. https://doi.org/10.2527/ 1993.71138x.

Ivan, S. K., R. J. Grant, D. Weakley, and J. Beck. 2005. Comparison of a corn silage hybrid with high cell-wall content and digestibility with a hybrid of lower cell-wall content on performance of Holstein cows. J. Dairy Sci. 88:244-254. https://doi.org/10.3168/jds.S0022 $-0302(05) 72682-5$

Jung, H.-J. G. 1997. Analysis of forage fiber and cell walls in ruminant nutrition. J. Nutr. 127:810S-813S. https://doi.org/10.1093/jn/127 $.5 .810 \mathrm{~S}$.

Krizsan, S. J., S. Ahvenjärvi, and P. Huhtanen. 2010. A meta-analysis of passage rate estimated by rumen evacuation with cattle and evaluation of passage rate prediction models. J. Dairy Sci 93:5890-5901. https://doi.org/10.3168/jds.2010-3457.

Krizsan, S. J., H. Gidlund, F. Fatehi, and P. Huhtanen. 2017. Effect of dietary supplementation with heat-treated canola meal on ru- 
minal nutrient metabolism in lactating dairy cows. J. Dairy Sci. 100:8004-8017. https://doi.org/10.3168/jds.2017-12625.

Krizsan, S. J., Z. Mussadiq, M. Hetta, M. Ramin, L. Nyholm, and P. Huhtanen. 2014. Predicting feeding value of forage maize hybrids harvested at different maturities and sites. J. Anim. Feed Sci. 23:269-278. https://doi.org/10.22358/jafs/65690/2014.

Lee, C., and A. N. Hristov. 2013. Short communication: Evaluation of acid-insoluble ash and indigestible neutral detergent fiber as totaltract digestibility markers in dairy cows fed corn silage-based diets. J. Dairy Sci. 96:5295-5299. https://doi.org/10.3168/jds.2012 -6442 .

Lee, C., A. N. Hristov, T. W. Cassidy, K. S. Heyler, H. Lapierre, G. A. Varga, M. J. de Veth, R. A. Patton, and C. Parys. 2012. Rumenprotected lysine, methionine, and histidine increase milk protein yield in dairy cows fed a metabolizable protein-deficient diet. J. Dairy Sci. 95:6042-6056. https://doi.org/10.3168/jds.2012-5581.

Lin, L. I. 1989. A concordance correlation coefficient to evaluate reproducibility. Biometrics 45:255-268. https://doi.org/10.2307/ 2532051.

Lippke, H. 1986. Regulation of voluntary intake of ryegrass and sorghum forages in cattle by indigestible neutral detergent fiber. J. Anim. Sci. 63:1459-1468. https://doi.org/10.2527/jas1986 $6351459 \mathrm{x}$

Lopes, F., K. Ruh, and D. K. Combs. 2015. Validation of an approach to predict total-tract fiber digestibility using a standardized in vitro technique for different diets fed to high-producing dairy cows. J. Dairy Sci. 98:2596-2602. https://doi.org/10.3168/jds.2014-8665.

Lopes, J. C., M. T. Harper, F. Giallongo, J. Oh, L. Smith, A. M. Ortega-Perez, S. A. Harper, A. Melgar, D. M. Kniffen, R. A. Fabin, and A. N. Hristov. 2017. Effect of high-oleic acid soybeans on production performance, milk fatty acid composition, and enteric methane emission in dairy cows. J. Dairy Sci. 100:1122-1135. https://doi.org/10.3168/jds.2016-11911.

Mehrez, A. Z., and E. R. Ørskov. 1977. A study of the artificial fibre bag technique for determining the digestibility of feeds in the rumen. J. agric. Sci. (Camb.) 88:645-650.

Melgar, A., M. T. Harper, J. Oh, F. Giallongo, M. E. Fetter, T. L. Ott, S. Duval, and A. N. Hristov. 2018. Effects of 3-nitrooxypropanol on rumen fermentation, lactational performance, and onset of ovarian activity in dairy cows. J. Dairy Sci. 101(Suppl. 2):198.

Morris, D. L., L. R. Rebelo, P. A. Dieter, and C. Lee. 2018. Validating intrinsic markers and optimizing spot sampling frequency to estimate fecal outputs. J. Dairy Sci. 101:7980-7989. https://doi.org/ $10.3168 /$ jds.2018-14717.

Mowrey, A., and J. N. Spain. 1999. Results of a nationwide survey to determine feedstuffs fed to lactating dairy cows. J. Dairy Sci. 82:445-451. https://doi.org/10.3168/jds.S0022-0302(99)75251-3.

Nousiainen, J., S. Ahvenjärvi, M. Rinne, M. Hellämäki, and P. Huhtanen. 2004. Prediction of indigestible cell wall fraction of grass silage by near infrared reflectance spectroscopy. Anim. Feed Sci. Technol. 115:295-311. https://doi.org/10.1016/j.anifeedsci 2004.03.004

Nousiainen, J., M. Rinne, and P. Huhtanen. 2009. A meta-analysis of feed digestion in dairy cows. 1 . The effects of forage and concentrate factors on total diet digestibility. J. Dairy Sci. 92:5019-5030. https://doi.org/10.3168/jds.2008-1833.

NRC. 2001. Nutrient Requirements of Dairy Cattle. 7th rev. ed. Natl. Acad. Press, Washington, DC.

Oba, M., and M. S. Allen. 1999. Evaluation of the importance of the digestibility of neutral detergent fiber from forage: Effects on dry matter intake and milk yield of dairy cows. J. Dairy Sci. 82:589596. https://doi.org/10.3168/jds.S0022-0302(99)75271-9.

Oh, J., M. Harper, A. Melgar, E. Wall, and A. Hristov. 2017. Production effects of phytonutrients alone or in combination with yeast culture in lactating dairy cows. J. Dairy Sci. 100(Suppl. 2):322.

Oh, J., M. T. Harper, and A. N. Hristov. 2019. Effects of lowering crude protein supply alone or in a combination with essential oils on productivity, rumen function and nutrient utilization in dairy cows. Animal. https://doi.org/10.1017/S1751731119001083 (accepted).
Ørskov, E. R., and I. McDonald. 1979. The estimation of protein degradability in the rumen from incubation measurements weighted according to rate of passage. J. Agric. Sci. (Camb.) 92:499-503. https://doi.org/10.1017/S0021859600063048.

Palmonari, A., A. Gallo, M. Fustini, G. Canestrari, F. Masoero, C. J. Sniffen, and A. Formigoni. 2016. Estimation of the indigestible fiber in different forage types. J. Anim. Sci. 94:248-254. https:// doi.org/10.2527/jas.2015-9649.

Pang, D., T. Yan, E. Trevisi, and S. J. Krizsan. 2018. Effect of grainor by-product-based concentrate fed with early or late harvested first-cut grass silage on dairy cow performance. J. Dairy Sci. 101:7133-7145. https://doi.org/10.3168/jds.2018-14449.

Raffrenato, E., C. F. Nicholson, and M. E. Van Amburgh. 2019. Development of a mathematical model to predict pool sizes and rates of digestion of 2 pools of digestible neutral detergent fiber and an undigested neutral detergent fiber fraction within various forages. J. Dairy Sci. 102:351-364. https://doi.org/10.3168/jds.2018-15102.

Raffrenato, E., D. A. Ross, and M. E. Van Amburgh. 2018. Development of an in vitro method to determine rumen undigested aNDFom for use in feed evaluation. J. Dairy Sci. 101:9888-9900. https: //doi.org/10.3168/jds.2018-15101.

Räisänen, S. E., C. M. M. R. Martins, K. Nedelkov, J. Oh, M. T. Harper, X. Chen, C. Parys, R. A. Patton, M. Miura, and A. N. Hristov. 2018. Bioavailability of rumen-protected histidine, lysine and methionine assessed by fecal amino acid excretion. J. Dairy Sci. 101(Suppl. 2):129

Sanderson, M. A. 1993. Aerobic stability and in vitro fiber digestibility of microbially inoculated corn and sorghum silages. J. Anim. Sci. 71:505-514. https://doi.org/10.2527/1993.712505x.

Schalla, A., L. Meyer, Z. Meyer, S. Onetti, A. Schultz, and J. Goeser. 2012. Hot topic: Apparent total-tract nutrient digestibilities measured commercially using 120 -hour in vitro indigestible neutral detergent fiber as a marker are related to commercial dairy cattle performance. J. Dairy Sci. 95:5109-5114. https://doi.org/10.3168/ jds.2012-5650.

Sluiter, A., B. Hames, R. Ruiz, C. Scarlata, J. Sluiter, and D. Templeton. 2006. Determination of sugars, byproducts, and degradation products in liquid fraction process samples. Laboratory Analytical Procedure (LAP) \#7. National Renewable Energy Laboratory, Golden, CO

Sluiter, A., B. Hames, R. Ruiz, C. Scarlata, J. Sluiter, D. Templeton, and D. Crocker. 2008. Determination of structural carbohydrates and lignin in biomass; Laboratory Analytical Procedure (LAP) procedure \#6. National Renewable Energy Laboratory. Golden, CO., USA.

Smith, L. W., H. K. Goering, and C. H. Gordon. 1972. Relationships of forage compositions with rates of cell wall digestion and indigestibility of cell walls. J. Dairy Sci. 55:1140-1147. https://doi.org/10 .3168/jds.S0022-0302(72)85636-4.

Traxler, M. J., D. G. Fox, P. J. Van Soest, A. N. Pell, C. E. Lascano, D. P. D. Lanna, J. E. Moore, R. P. Lana, M. Velez, and A. Flores. 1998. Predicting forage indigestible NDF from lignin concentration. J. Anim. Sci. 76:1469-1480. https://doi.org/10.2527/1998 $.7651469 \mathrm{x}$.

Van Amburgh, M. E., P. J. Van Soest, J. B. Robertson, and W. F. Knaus. 2003. Corn silage neutral detergent fiber: Refining a mathematical approach for in vitro rates of digestion. Pages 99-108 in Proc. Cornell Nutr. Conf., Syracuse, NY. Dept. of Anim. Sci. Cornell University, Ithaca, NY.

Van Soest, P. J. 1967. Development of a comprehensive system of feed analyses and its application to forages. J. Anim. Sci. 26:119-128. https://doi.org/10.2527/jas1967.261119x.

Van Soest, P. J., J. B. Robertson, and B. A. Lewis. 1991. Methods for dietary fiber, neutral detergent fiber, and nonstarch polysaccharides in relation to animal nutrition. J. Dairy Sci. 74:3583-3597. https://doi.org/10.3168/jds.S0022-0302(91)78551-2.

Van Soest, P. J., R. H. Wine, and L. A. Moore. 1966. Estimation of the true digestibility of forages by the in vitro digestion of cell walls. Pages 438-441 in Proc. X Int. Grassland Congr., Helsinki, Finland. 
Weeks, H. L., T. W. Frederick, L. M. Hagan, K. Heyler, J. Oh, and A. N. Hristov. 2015. Case study: Farm-level evaluation of implementing nitrogen and phosphorus feeding best management practices on Pennsylvania dairy farms. Prof. Anim. Sci. 31:473-483. https:/ /doi.org/10.15232/pas.2015-01400.

Weisbjerg, M. R., V. Koukolová, and P. Lund. 2007. Rate of NDF degradation. J. Anim. Feed Sci. 16(Suppl. 2):151-155. https://doi .org $/ 10.22358 /$ jafs $/ 74474 / 2007$.

Wilkins, R. J. 1969. The potential digestibility of cellulose in forage and faeces. J. Agric. Sci. (Camb.) 73:57-64.

Young, K. M., J. M. Lim, M. C. Der Bedrosian, and L. Kung Jr.. 2012. Effect of exogenous protease enzymes on the fermentation and nutritive value of corn silage. J. Dairy Sci. 95:6687-6694. https:// doi.org/10.3168/jds.2012-5628.

\section{ORCIDS}

A. N. Hristov (1) https://orcid.org/0000-0002-0884-4203

M. T. Harper ๑ https://orcid.org/0000-0002-9480-3298

G. Roth ( ) https://orcid.org/0000-0003-1072-9201

P. Huhtanen (๑) https://orcid.org/0000-0001-7855-7448

T. L. Richard ๑ https://orcid.org/0000-0002-0833-4844

K. DiMarco @ https://orcid.org/0000-0002-1269-8130

\section{APPENDIX}

Table A1. Effect of hybrid (H) and ensiling time (ET) on corn silage lignin and cell-wall carbohydrates (as $\%$ of $\mathrm{DM})^{1}$

\begin{tabular}{|c|c|c|c|c|c|c|}
\hline \multirow[b]{2}{*}{ Variable } & \multicolumn{3}{|c|}{ Corn silage hybrid ${ }^{2}$} & \multirow[b]{2}{*}{ SEM } & \multicolumn{2}{|c|}{$P$-value ${ }^{3}$} \\
\hline & HUB1 & $\mathrm{MC}$ & $\mathrm{HHG}$ & & $\mathrm{H}$ & $\mathrm{ET}$ \\
\hline$\overline{\text { Lignin }}$ & $15.1^{\mathrm{ab}}$ & $15.7^{\mathrm{a}}$ & $14.7^{\mathrm{b}}$ & 0.28 & 0.01 & 0.47 \\
\hline Glucan & $38.7^{\mathrm{b}}$ & $40.7^{\mathrm{a}}$ & $39.1^{\mathrm{b}}$ & 0.51 & 0.009 & 0.35 \\
\hline Xylan & $27.6^{\mathrm{a}}$ & $27.3^{\mathrm{a}}$ & $25.2^{\mathrm{b}}$ & 0.43 & $<0.001$ & 0.74 \\
\hline Galactan & $1.49^{\mathrm{a}}$ & $1.36^{\mathrm{b}}$ & $1.54^{\mathrm{a}}$ & 0.047 & 0.006 & 0.19 \\
\hline Arabinan & 5.07 & 4.94 & 4.76 & 0.133 & 0.18 & 0.21 \\
\hline Total $^{4}$ & $86.5^{\mathrm{b}}$ & $90.2^{\mathrm{a}}$ & $84.8^{\mathrm{b}}$ & 1.36 & 0.004 & 0.64 \\
\hline Unaccounted $^{5}$ & $13.5^{\mathrm{a}}$ & $9.7^{\mathrm{b}}$ & $15.2^{\mathrm{a}}$ & 1.36 & 0.004 & 0.64 \\
\hline
\end{tabular}

${ }^{\mathrm{a}, \mathrm{b}}$ Means with different superscripts differ at $P<0.05$.

${ }^{1}$ Only ensiling times 0-, 30-, and 120-d were analyzed for cell-wall carbohydrates.

${ }^{2}$ The following hybrids were selected for this analysis: Hubner H5333RC3P (HUB1, Hubner Seed, Monticello, IN; only 0 and 30 d), Masters Choice MC 5250 (MC, Masters Choice, Anna, IL), and Healthy Herd Genetics 42HFC15 (HHG, Healthy Herd Genetics and Nutrition, Greenport, NY).

${ }^{3}$ Effects of corn silage hybrid $(\mathrm{H})$ and ensiling time $(\mathrm{ET})$; largest SEM presented; $\mathrm{n}=22$. We found no hybrid $\times$ ensiling time interaction for any of the cell-wall carbohydrates $(P \geq 0.18)$, except for arabinan $(P<0.001$; see Results and Discussion).

${ }^{4}$ Sum of the above analyses.

${ }^{5}$ Difference to $100 \%$; mostly ash, but also includes proteins, lipids, and other minor insoluble constituents. 